\title{
In Vitro Shoot Induction of Musa acuminata cv. Mas Kirana
}

\author{
Raden Roro Rifka Annisa'), Arkan Setiajii), Aries Bagus Sasongko' ${ }^{2)}$ \\ ${ }^{1}$ Undergraduate Program of Biology, Faculty of Biology, Gadjah Mada University \\ ${ }^{2}$ Laboratory of Biotechnology, Faculty of Biology, Gadjah Mada University \\ e-mail: ariesbaguss@ugm.ac.id
}
APA Citation: Annisa, R.R.R., Setiaji, A. \& Sasongko, A.B. (2021). In Vitro Shoot Induction of Musa acuminata cv. Mas Kirana. Quagga: Jurnal Pendidikan dan Biologi, 13(1), 34-41. doi: 10.25134/quagga.v13i1.3431.

Received: 30-09-2020

Accepted: 04-11-2020

Published: 01-01-2021

\begin{abstract}
The availability of 'mother plants' used for source of explants is one of the most important limitations for the development of in vitro culture in new banana cultivar's. To increase produce large quantities of uniform and healthy seedlings, induction of multiplication has been carried out on Musa acuminata cv. Mas Kirana. Plant regeneration were obtained by culturing sucker on MS medium supplemented with PGRs BAP and NAA (1 mg/l $+0.5 \mathrm{mg} / \mathrm{l}, 2 \mathrm{mg} / \mathrm{l}+0.5 \mathrm{mg} / \mathrm{l}$, and $3 \mathrm{mg} / \mathrm{l}+0.5 \mathrm{mg} / \mathrm{l})$ and $\mathrm{TDZ}(0.25 \mathrm{mg} / \mathrm{l}, 0.5 \mathrm{mg} / \mathrm{l}$, and $0.75 \mathrm{mg} / \mathrm{l})$. The highest shoot formation was found in $0.25 \mathrm{mg} / \mathrm{l} \mathrm{TDZ}$ with average shoots of $13.67 \pm 3.16$ and primary shoot height is 20 $\mathrm{cm}$. TDZ induction tends to form somatic embryos, while induction of BAP and NAA leads to organogenesis. The rate of contaminants occurrence from bacteria is $87.50 \%$ and $12.50 \%$ from fungus. In histological observation, TDZ, BAP, and NAA affect the development of many new meristematic zones seen in the scalps.
\end{abstract}

Keywords: shoot induction; Musa acuminata; sucker explant; organogenesis; in vitro culture

\begin{abstract}
Abstrak: Ketersediaan tanaman induk sebagai sumber eksplan merupakan salah satu faktor pembatas bagi pengembangan teknik kultur in vitro pada kultivar-kultivar baru tanaman pisang. Untuk meningkatkan produksi dalam jumlah besar pada bibit-bibit yang sehat dan seragam, induksi multiplikasi tunas telah dilakukan pada Musa acuminata cv. Mas Kirana. Regenerasi tanaman dilakukan dengan menumbuhkan eksplan 'anakan pedang' pada medium MS yang ditambahkan ZPT BAP dan NAA (1 mg/l + 0,5 mg/l, $2 \mathrm{mg} / \mathrm{l}+0,5 \mathrm{mg} / \mathrm{l}$, and $3 \mathrm{mg} / \mathrm{l}+0,5$ $\mathrm{mg} / \mathrm{l})$ dan $\operatorname{TDZ}(0,25 \mathrm{mg} / \mathrm{l}, 0,5 \mathrm{mg} / \mathrm{l}$, dan $0,75 \mathrm{mg} / \mathrm{l})$. Pembentukan tunas terbanyak ditemukan pada medium dengan 0,25 mg/l TDZ dengan rata-rata jumlah tunas sebanyak 13,67 \pm 3,16 dan rata-rata panjang tunas primer $20 \mathrm{~cm}$. Induksi dengan TDZ mengarah pada pembentukan embrio somatik, sedangkan induksi dengan BAP dan NAA mengarah pada organogenesis. Tingkat kontaminasi yang berasal dari bakteri adalah $87.50 \%$ dan dari jamur sebanyak 12.50\%. Pada pengamatan secara histologis, ZPT TDZ, BAP, dan NAA memengaruhi terbentuknya sekumpulan zona meristematik yang terdapat di dalam skalp.
\end{abstract}

Kata Kunci: induksi tunas; Musa acuminata; eksplan anakan-pedang; organogenesis; kultur in vitro

\section{INTRODUCTION}

Banana is the common name of genus $\mathrm{Musa}$ sp., having great importance in the world due to its commercial importance and high nutritional value. Among Eumusa species of banana, Musa acuminata is the most widespread, with Malaysia or Indonesia as its center of diversity (Aquil et al., 2012). One of the cities in Indonesia that has been the center of production of Musa acuminata is Lumajang, East Java, and the new superior cultivar of it is Mas Kirana (Musa acuminata cv. Mas Kirana) (Prahardini et al., 2018). This banana is important to be cultivated as local superior products because of their high productivity, long round fruit shape, almost lack of fruit ridges, clean yellow fruit skin, and bright yellow flesh with sweet taste. The high demand for Mas Kirana banana seedlings was not correlated with the availability of quality and uniform seeds. In general, seeds are produced by the multiplication of humps, and there is a risk of carrying diseases from the parent tree, such as blood disease (Blood Disease Bacteria (BDB)) caused by Ralstonia solanacearum Race 2 and Fusarium wilt due to Fusarium oxysporum infection. These two pathogens are land-borne diseases, meaning that if consumers plant infected seeds, the infection can spread on other lands, causing losses both in terms of fruit productivity and handling the disease.

One of the best techniques to produce disease-free seedlings is the in vitro plant culture. Various types of explants have been used to regenerate banana plantlets, including shoot buds (Remakanthan et al., 2014; Saeedavi 
et al., 2017), flowering buds (Resmi et al., 2007), zygotic embryos (Uma et al., 2012), the results of meristem and scalp division (Elhory et al., 2009; Shirani et al., 2010; Sipen and Davey, 2012), male flowers (Grapin et al., 2000) and female flowers (Divakaran and Nair, 2011; Jalil et al., 2003; Sidha et al., 2006; Xiao et al., 2007). As for work effectiveness and if there are large quantities of bananas available, a sucker as a source of explants can be chosen.

Thidiazuron (TDZ) is one of the synthetic phenylurea type cytokines that have better ability to induce shoots, among other cytokines such as zeatin, benzylaminopurine, and kinetin (Mok and Mok, 2001; Kuo et al., 2005). The 6Benzylaminopurine (BAP) is a plant growth regulator in the cytokinin group commonly used to increase and induce shoot regeneration, somatic embryogenesis, cell division, and axillary bud growth (Chawla, 2011). BAP is a first-generation synthetic cytokinin that is commonly applied to stimulate shoot proliferation and control cell division when combined with auxin (Habiba et al., 2014). One of the auxins that can be combined with BAP is 1-Naphthaleneacetic Acid (NAA). In a previous study, a combination of $1.5 \mathrm{mg} / 1$ NAA with 5 $\mathrm{mg} / \mathrm{l}$ BAP showed optimal results in the formation, amount, and height of shoots of Musa acuminata L. in 80 days (Yudha et al., 2015).

Based on the description above, a study was conducted on the effect of TDZ, BAP, and NAA on Mas Kirana banana micropropagation and histological examination of the explant.

\section{RESEARCH METHODOLOGY}

The banana suckers were collected from the field of a local farmer in Lumajang, East Java. Suckers were trimmed to $3-5 \mathrm{~cm}$, containing the shoot meristem. Explants were surface sterilized in $5.25 \% \mathrm{NaOCl}$ solution for 5 minutes, then washed in sterile distilled water three times before soaked in $70 \%$ ethanol for a while and double washed again in sterile distilled water. Leaf-sheaths were removed and trimmed into 1$2 \mathrm{~cm}$ then cut into 4 equal parts in the laminar airflow cabinet. Explant then inoculated in MS medium (Murashige and Skoog, 1962) supplemented with BAP + NAA $(1 \mathrm{mg} / 1+0.5$ $\mathrm{mg} / 1,2 \mathrm{mg} / 1+0.5 \mathrm{mg} / 1$, and $3 \mathrm{mg} / 1+0.5 \mathrm{mg} / 1$ ), TDZ $(0.25 \mathrm{mg} / 1,0.5 \mathrm{mg} / \mathrm{l}$, and $0.75 \mathrm{mg} / \mathrm{l}), 3 \%$ sucrose (w/v), $0.7 \%$ agar (w/v), and the $\mathrm{pH}$ was adjusted to $4.8-5.6$ before sterilized in autoclave at $121^{\circ} \mathrm{C}$ for 15 minutes. The cultures were maintained at a temperature of $22 \pm 2^{\circ} \mathrm{C}$. The culture transferred to fresh medium every 4 weeks at the same PGRs concentrations.

The regenerants formed were sampled for histological analysis. Sample was fixed in FAA (90 $\mathrm{ml} 70 \%$ EtOH, $5 \mathrm{ml}$ acetic acid, and $5 \mathrm{ml} 36$ $\%$ formaldehyde) solution. Sample was washed repeatedly in $70 \% \mathrm{EtOH}$ and dehydrated with ethanol series $(80 \%, 90 \%$ and $95 \%)$. Sequently dealcoholization using absolute ethanol and xylene mixture i.e.: ethanol/xylene $3: 1 ; 1: 1$; and $1: 3$, followed by infiltration in the mixture of liquid paraffin and xylene $(9: 1)$ for 24 hours. Before embedded, the sample was immersed in pure liquid paraffin for one hour and then embedded using the pure paraffin. The embedded sample was sectioned into thinly slide using rotary microtome. The sliced sample was stained with $1 \%$ safranin in $70 \%$ ethanol. After staining, the slides were observed under the light microscope and the photograph was taken using the OptiLab Viewer 2.2.

\section{RESULT AND DISCUSSION}

In the first month after inoculation, all explants have not shown any formation of new structures (Fig. 1). However, there are changes in the color of explants. Initially, the explants used has white color, but after one month after inoculation explants were turned green. This indicated the presence of chlorophyll production. Instead of growing new shoots, explants produce chlorophyll first to produce more energy for the next differentiation. Chlorophyll is one of the basic pigments that plants need in photosynthesis (Fraser et al., 2001). Cytokinins, as one of the important growth regulators in plant tissue culture, play a role in the process of producing shoots and pigments and inhibit senescence or aging (Stirk and Van Staden, 2010). 


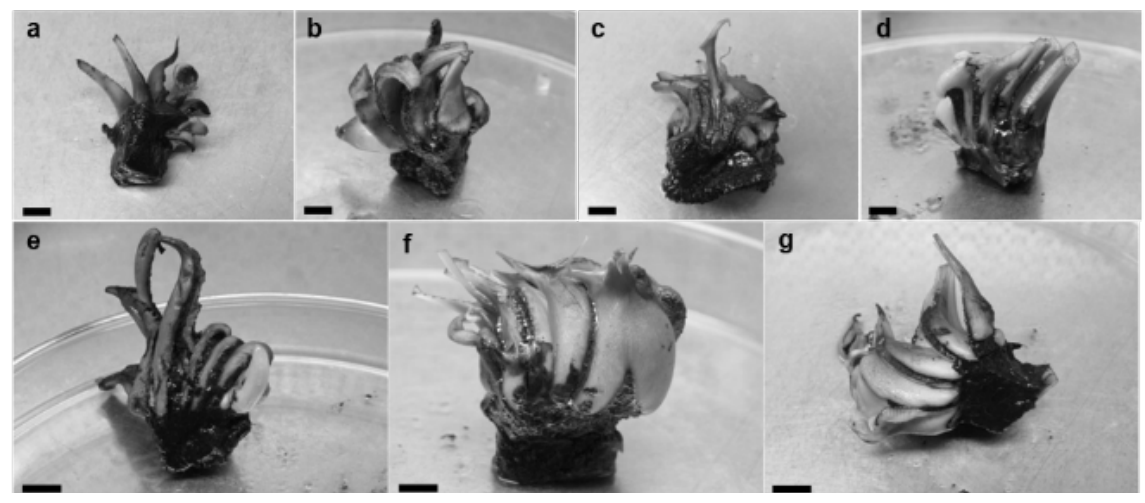

Figure 1. Morphological changes of explant at the first month after inoculation. (a) MS medium without any addition as control (b). MS medium supplemented with BAP $1 \mathrm{mg} / \mathrm{l}+\mathrm{NAA}$ $0.5 \mathrm{mg} / 1$ (c). MS medium supplemented with BAP $2 \mathrm{mg} / 1+\mathrm{NAA} 0.5 \mathrm{mg} / 1$ (d). MS medium supplemented with BAP $3 \mathrm{mg} / 1$ + NAA $0.5 \mathrm{mg} / 1$ (e). MS medium supplemented with TDZ $0.25 \mathrm{mg} / \mathrm{l}(\mathrm{f})$. MS medium supplemented with TDZ $0.50 \mathrm{mg} / \mathrm{l}(\mathrm{g})$. MS medium supplemented with TDZ $0.75 \mathrm{mg} / \mathrm{l}$. Bar $=10 \mathrm{~mm}$.

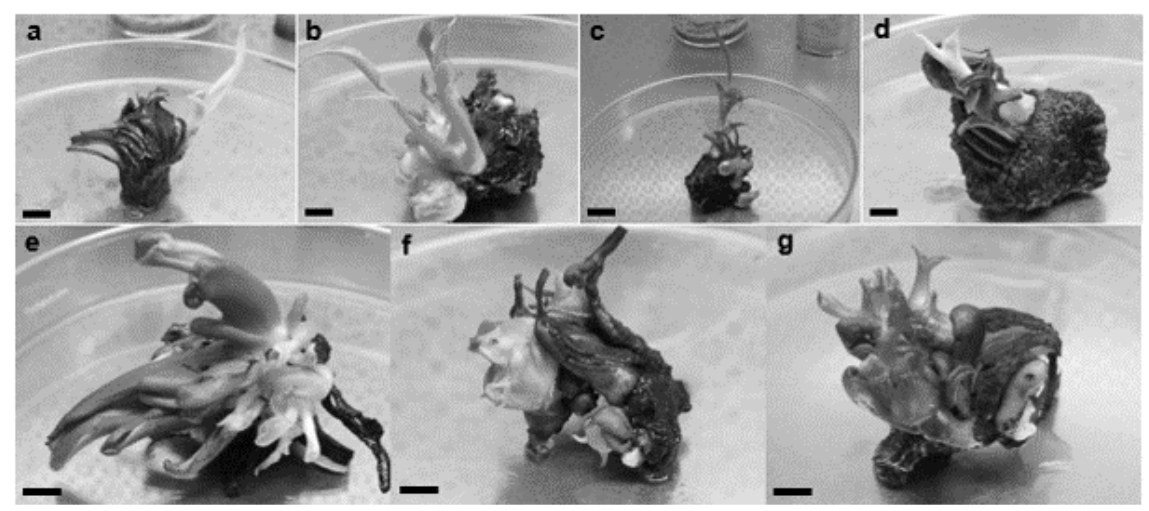

Figure 2. Morphological changes of explant at the third month after inoculation. (a). MS medium without any addition as control (b). MS medium supplemented with BAP $1 \mathrm{mg} / \mathrm{l}+\mathrm{NAA}$ $0.5 \mathrm{mg} / 1$ (c). MS medium supplemented with BAP $2 \mathrm{mg} / 1+\mathrm{NAA} 0.5 \mathrm{mg} / 1$ (d). MS medium supplemented with BAP $3 \mathrm{mg} / 1$ + NAA $0.5 \mathrm{mg} / 1$ (e). MS medium supplemented with TDZ $0.25 \mathrm{mg} / \mathrm{l}$ (f). MS medium supplemented with TDZ $0.50 \mathrm{mg} / \mathrm{l}$ (g). MS medium supplemented with TDZ $0.75 \mathrm{mg} / 1$. Bar $=10 \mathrm{~mm}$.

New structure formation began to appear in the third month after inoculation (Fig. 2). The result shows that combination of BAP and NAA produced shoot through organogenesis rather than embryos. The best response was obtained in BAP $2 \mathrm{mg} / 1+\mathrm{NAA} 0.5 \mathrm{mg} / 1$, which produces about 2-3 shoots with the highest average shoot height compared to other treatments, about 66 $\mathrm{mm}$ (Table 1). The same results are shown by Govindaraju et al., (2012), that the best shoot proliferation is found in BAP $2 \mathrm{mg} / \mathrm{l}$ using sword suckers. Abeyaretne and Lathiff (2002) show that induction of 2-3 mg/l BAP on basal media is recommended for shoot tips culture of bananas. The combination of BA and NAA induction can maximize shoot multiplication in shoot tips as explants in various studies
(Rahman et al., 2004; Suprasanna et al., 2008). Rahman et al. (2002) show that BAP was effective in shoot proliferation compared to other cytokines. Cytokinins such as benzyl aminopurine (BAP) are generally known to reduce the dominance of apical shoots and induce axillary and adventitious shoot formation from meristematic explants in bananas, and the banana tip culture system is best obtained by using BAP addition to the media (Jafari et al., 2011).

Meanwhile, TDZ induction shows the presence of somatic embryo formation (Fig. 2). The best response was obtained in TDZ 0.25 $\mathrm{mg} / \mathrm{l}$, which produces 13 shoots, with an average shoot height of about $20 \mathrm{~mm}$ (Table 1). 
Tabel 1. Effect of various concentration of PGRs on explant development after 5 month of culture

\begin{tabular}{|c|c|c|c|c|c|c|}
\hline \multicolumn{3}{|c|}{ PGR (mg/l) } & \multirow{2}{*}{ Buds Total } & \multirow{2}{*}{$\begin{array}{l}\text { Buds Length } \\
\text { (mm) }\end{array}$} & \multirow{2}{*}{ Leaves Total } & \multirow{2}{*}{ Roots Total } \\
\hline $\mathbf{B A}$ & $\mathbf{N A A}$ & TDZ & & & & \\
\hline- & - & - & $1.00 \pm 3.16^{\mathrm{a}}$ & $45.70 \pm 19.94^{\mathrm{a}}$ & $2.00 \pm 4.40^{\mathrm{a}}$ & $2.00 \pm 0.52^{b}$ \\
\hline 1 & 0.5 & - & $3.00 \pm 3.16^{\mathrm{a}}$ & $29.23 \pm 19.94^{a}$ & $3.00 \pm 4.40^{\mathrm{a}}$ & $0.33 \pm 0.52^{\mathrm{ab}}$ \\
\hline 2 & 0.5 & - & $2.70 \pm 3.16^{\mathrm{a}}$ & $66.10 \pm 19.94^{3}$ & $4.33 \pm 4.40^{\mathrm{a}}$ & $1.00 \pm 0.52^{\mathrm{ab}}$ \\
\hline 3 & 0.5 & - & $0.34 \pm 3.16^{\mathrm{a}}$ & $6.67 \pm 19.94^{\mathrm{a}}$ & $0.67 \pm 4.40^{\mathrm{a}}$ & $0.67 \pm 0.52^{\mathrm{ab}}$ \\
\hline- & - & 0.25 & $13.67 \pm 3.16^{b}$ & $20.00 \pm 19.94^{\mathrm{a}}$ & $13.67 \pm 4.40^{\mathrm{a}}$ & 0 \\
\hline- & - & 0.50 & $2.67 \pm 3.16^{a}$ & $36.67 \pm 19.94^{a}$ & $8.33 \pm 4.40^{\mathrm{a}}$ & 0 \\
\hline- & - & 0.75 & $8.33 \pm 3.16^{\mathrm{ab}}$ & $16.00 \pm 19.94^{\mathrm{a}}$ & $10.33 \pm 4.40^{\mathrm{a}}$ & 0 \\
\hline
\end{tabular}

Divakaran and Nair (2011) used the same concentration and obtained results that at a concentration of $1.35 \mu \mathrm{M}(0.25 \mathrm{mg} / \mathrm{l})$ produced the most embryos in Matti (AA) and Chingan (AB) cultivars on the 90th day. Arinaitwe et al. (2000) reported that TDZ is effective for the proliferation of banana cultivars. The proliferation of banana buds is dependent on each cultivar, and each explant has an optimal concentration in maximizing the proliferation response. Shoot proliferation response in TDZ induction was stronger than BAP in all types of bananas in the study (Gübbük and Pekmezci, 2004). Based on previous studies it can be seen that TDZ concentration has a large role in bud multiplication and elongation in banana shoot culture. Based on recent studies, TDZ is more effective in producing healthier shoots in vitro propagation than other cytokines (Smitha et al., 2014).

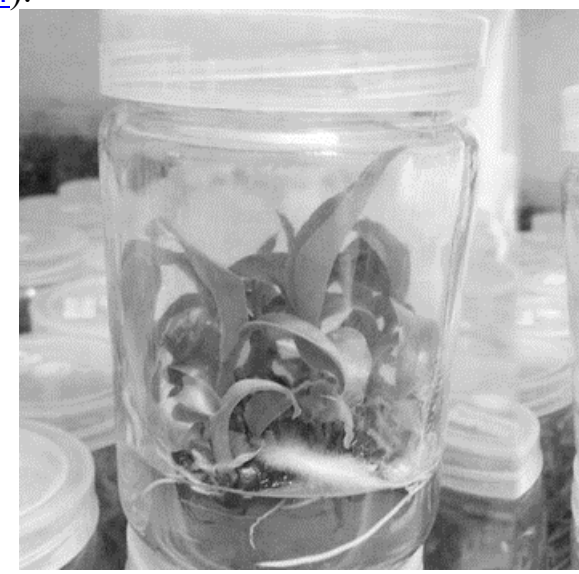

Figure 4. Planlets of $M$. acuminata $\mathrm{cv}$. Mas Kirana after 5 month of culture on MS medium with $2 \mathrm{mg} / 1 \mathrm{BAP}+0.5$ $\mathrm{mg} / \mathrm{lNAA}$
In the present study, the explants were grown on Murashige and Skoog medium that is widely used for commercial production of planlets from banana, tuberous, and woody plants. This medium contains high concentrations of ammonia, potassium, and nitrates; and relatively cheaper compared to other mediums like the White medium (Stewart $\mathrm{Jr}, 2016$ ). Some of the authors made modifications to this basal medium, such as the supplementation of additive organic complex, variations in carbon sources, vitamins, or even the strengthened of the medium, all of them aim to obtain the low cost of banana culture procedures with effective effect on propagation (Strosse et al., 2004).

The level of explant contamination was observed. About $28.57 \%$ of the culture was contaminated. Contamination agents mostly coming from bacteria $(87.50 \%)$, while the rest were coming from fungus $(12.50 \%)$. The high rate of contamination caused by the explant source is taken from the field. In banana micropropagation, contamination by bacteria is very influential in the survival of explants. Although sterilization on the explant surface is successful, contamination by bacteria can still be found in the basal part of the explants. Bacterial growth can also occur in culture media (Titov et al., 2006). The high number of explant damage occurs because of the presence of endogenous bacteria and other microbes that are resistant to occurs because of the presence of endogenous 

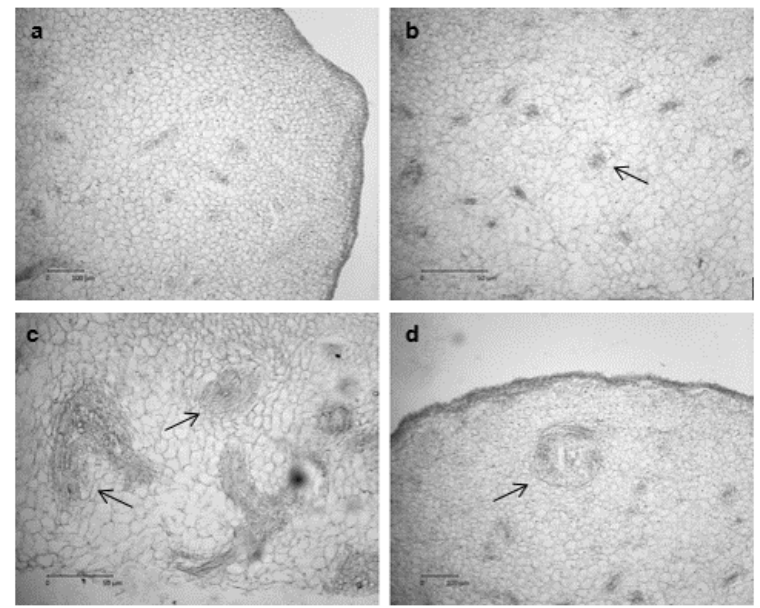

Figure 4. Histological view of explant's scalp. (a). scalp's dome (b). longitudinal sections showing clumps of meristematic tissue (arrow: meristematic tissue) (c)-(d). longitudinal sections showing new somatic embryo (arrow: somatic embryo)

bacteria and other microbes that are resistant to surface sterilization (Rayaprolu et al., 2015). The several bacterial genera that are often found as contaminant agents in in-vitro banana cultures (Musa spp.) Include Proteus, Erwinia, Klebsiella, and Staphylococcus. While for the fungi genus that is often found in banana culture include Aspergillus, Fusarium, Penicillium, and Candida (Msogoya et al., 2012).

In most cases, endophytic contaminant is not easily controlled. It is difficult to controlled bacteria contamination, meanwhile, endophytic fungus could be prevented by using contact or systemic fungicides. Broad-spectrum antibiotic with low phytotoxicity is suitable for better results (Ray and Ali, 2016). During preliminary study, we have been using Plant Preservative Mixture $^{\mathrm{TM}}$ (PPM) (Plant Cell Technology, Washington, D.C.), a mix up of active compounds methylisothiazolone and methylchloroisothiazolinone by using concentration $0.75-2.0 \mathrm{ml} / 1$ but still not produce uniform sterile explants. The contaminants can reduced by maintaining optimum aseptic conditions during taking and culturing explants, along incubation.

Browning is also observed in explants. For about $33.33 \%$ of culture were browning. The level of browning in explants is higher than the level of contamination. Titov et al. (2006) showed that almost all explants used from inflorescence buds of Musa spp. cv. Kanthall, free of contamination, but had high levels of phenolic compounds accumulation. Phenolic compounds released by plant tissue will accumulate in culture media. This process is characterized by explant surfaces which become brownish due to oxidation of these phenolic compounds, resulting in the formation of quinones which are highly reactive and toxic to plant tissue. Browning can reduce the capacity of cell division and regeneration of explants. One way that can be done to reduce browning in vitro cultures is the application of absorbent compounds and antioxidant compounds (Singh, 2018). Mante and Tepper (1983) used antioxidant compounds in the form of a mixture of ascorbic acid + citric acid + cysteine and succeeded in suppressing the level of browning in the explants Musa textilis. As for Titov et al. (2006) using a combination of potassium citrate: citrate (K - C: C) also proved to reduce the level of browning in explants Musa spp. cv. Kanthall.

The initial structure of the somatic embryo observed from TDZ induction is a white dome called the scalp (Fig. 4). Based on histological observations, it can be seen that the scalp is composed of clumps of meristematic tissues (Fig. 3b), which then differentiate into somatic embryos (Fig. 3c-d). The same result was obtained in a study on other banana cultivars by Ganapathi et al. (2001), Khalil et al. (2002), and Divakaran and Nair (2011). The scalp has a high proliferative capacity that can be used for mass clonal propagation and can be used as a target material for induced mutations and genetic engineering (Siamak et al., 2010). Sadik et al. (2007) and Sholi et al. (2009) stated that scalp formation in shoots was dependent on cultivars and the medium used.

\section{CONCLUSION}

The highest shoot formation was found in MS medium supplemented by $0.25 \mathrm{mg} / 1 \mathrm{TDZ}$. TDZ induction tends to form somatic embryos, while induction of BAP and NAA leads to shoot induction. In histological observation, TDZ, BAP, and NAA affect the development of many new meristematic zones in the scalps.

\section{ACKNOWLEDGMENT}

The research was supported by the Ministry of Research, Technology, and Higher Education 
of the Republic of Indonesia through PKM Grant (No. 1020/B3.1/KM/2018).

\section{REFERENCES}

Abeyaratne, W.M. and M.A. Lathiff. 2002. In vitro propagation of Rathambala (Musa AAA) and the occurrence of phenotypic variations in the pseudostem. Annals of the Sri Lanka Department of Agriculture (LKA), 4: 191-197.

Aquil, B., A.T. Jan, N.B. Sarin, and Q.M.R. Haq. 2012. Micropropagation and genetic transformation of banana for crop improvement and sustainable agriculture. Journal of Crop Science, 3(2): 64-77.

Chawla, H. 2009. Introduction to Plant Biotechnology (3/e). Boca Raton: CRC Press.

Divakaran, S.P. and A.S. Nair. 2011. Somatic embryogenesis from bract cultures in diploid Musa acuminata cultivars from South India. Scientia horticulturae, 131: 99-102.

Elhory, S.M.A., M.A. Aziz, A.A. Rashid, and A.G. Yunus. 2009. Prolific plant regeneration through organogenesis from scalps of Musa sp cv. Tanduk. African Journal of Biotechnology, 8(22): 62086213.

Fraser, N.J., H. Hashimoto, and R.J. Cogdell. 2001. Carotenoids and bacterial photosynthesis: The story so far... Photosynthesis research, 70(3): 249-256.

Ganapathi, T.R., N.S. Higgs, P.J. Balint-Kurti, C.J. Arntzen, G.D. May and J.M. Van Eck. 2001. Agrobacterium-mediated transformation of embryogenic cell suspensions of the banana cultivar Rasthali (AAB). Plant Cell Reports, 20(2): 157-162.

Govindaraju, S., J. Saravanan, B. Jayanthi, D. Nancy, and I. Arulselvi. 2012. In vitro propagation of Banana (Musa sp-Rasthali variety) from sword suckers for its commercial production. Research in Plant Biology, 2(5).

Grapin, A., J.L. Ortiz, T. Lescot, N. Ferrière, and F.X. Côte. 2000. Recovery and regeneration of embryogenic cultures from female flowers of False Horn Plantain. Plant Cell, Tissue and Organ Culture, 61(3): 237-244.
Gübbük, H. and M. Pekmezci. 2004. In vitro propagation of some new banana types (Musa spp.). Turkish Journal of Agriculture and Forestry, 28(5): 355-361.

Habiba, S.U., K. Shimasaki, M.M. Ahasan, and M.M. Alam. 2014. Effect of different cytokinins on in vitro organogenesis in protocorm-like bodies (PLBs) of Epidendrum 'Rouge Star No. 8'. Middle East J. Sci. Res, 21: 1843-7.

Jafari, N., R.Y. Othman, and N. Khalid. 2011. Effect of benzylaminopurine (BA) pulsing on in vitro shoot multiplication of Musa acuminata (banana) cv. Berangan. African Journal of Biotechnology, 10(13): 2446-2450.

Jalil, M., N. Khalid, and R.Y. Othman. 2003. Plant regeneration from embryogenic suspension cultures of Musa acuminata cv. Mas (AA). Plant Cell, Tissue and Organ Culture, 75(3): 209-214.

Khalil, S., K. Cheah, E. Perez, D. Gaskill, and J. Hu. 2002. Regeneration of banana (Musa spp. AAB cv. Dwarf Brazilian) via secondary somatic embryogenesis. Plant Cell Reports, 20(12): 1128-1134.

Kuo, H.L., J.T. Chen, and W.C. Chang. 2005. Efficient plant regeneration through direct somatic embryogenesis from leaf explants of Phalaenopsis 'Little Steve'. In Vitro Cellular \& Developmental Biology-Plant, 4l(4).

Mante, S. and H.B. Tepper. 1983. Propagation of Musa textilis Nee plants from apical meristem slices in vitro. Plant Cell, Tissue and Organ Culture, 2(2): 151-159.

Mok, D.W. and M.C. Mok. 2001. Cytokinin metabolism and action. Annual review of plant biology, 52(1): 89-118.

Msogoya, T., H. Kanyagha, J. Mutigitu, M. Kulebelwa, and D. Mamiro. 2012. Identification and management of microbial contaminants of banana in vitro cultures. Journal of Applied Biosciences, 55: 3987-3994.

Murashige, T. and F. Skoog. 1962. A revised medium for rapid growth and bioassays with tobacco tissue cultures. Physiol. Plant. 15: 473-497.

Prahardini, P.E.R. and B.P.T.P.J. Timur. 2018. Karakterisasi Varietas Unggul Pisang Mas Kirana dan Agung Semeru di 
Kabupaten Lumajang. Buletin Plasma Nutfah, 16(2): 126-133.

Rahman, M.M., M.G. Rabbani, M.A. Rahman, and M.F. Uddin. 2002. In vitro shoot multiplication and rooting of banana cv. Sabri. Pakistan Journal of Biological Sciences, 5(2): 161-164.

Rahman, M.Z., K.M. Nasiruddin, M.A. Amin, and M.N. Islam. 2004. In vitro response and shoot multiplication of banana with BA and NAA. Asian Journal of Plant Sciences, 3(4): 406-409.

Ray, S.S. and N. Ali. 2017. Biotic contamination and possible ways of sterilization: A review with reference to bamboo micropropagation. Brazilian Archives of Biology and Technology, 59, e160485.

Rayaprolu, S., G. Mathian, and G. Ranjitha. 2015. Can in vitro contaminated culture be revived-A case study with contaminated cultures of tuberose (Polianthes tuberosa). Curr. Biotica, 9, 285-288.

Remakanthan, A., T.G. Menon, and E.V. Soniya. 2014. Somatic embryogenesis in banana (Musa acuminata AAA cv. Grand Naine): effect of explant and culture conditions. In Vitro Cellular \& Developmental Biology-Plant, 50(1): 127-136.

Resmi, L. and A.S. Nair. 2007. Plantlet production from the male inflorescence tips of Musa acuminata cultivars from South India. Plant cell, tissue and organ culture, 88(3): 333-338.

Sadik, K., P.R. Rubaihayo, M.J.S. Magambo, and M. Pillay. 2007. Generation of cell suspensions of East African highland bananas through scalps. African Journal of Biotechnology, 6(11): 1352-1357.

Saeedavi, L., A. Soleimani, and M.E. Amiri. 2017. Improvement of shoot-tip culture proliferation in banana using PEG 6000. Iranian Journal of Plant Physiology, 7(3).

Shirani, S., F. Mahdavi, and M. Maziah. 2009. Morphological abnormality among regenerated shoots of banana and plantain (Musa spp.) after in vitro multiplication with TDZ and BA from excised shoot tips. African Journal of Biotechnology, 8(21): 5755-5761.

Sholi, N.J., A. Chaurasia, A. Agrawal, and N.B. Sarin. 2009. ABA enhances plant regeneration of somatic embryos derived from cell suspension cultures of plantain cv. Spambia (Musa sp.). Plant Cell, Tissue and Organ Culture, 99(2): 133140.

Siamak, S., S. Meon, Z. Wahab, and M. Mahmood. 2010. Scalp induction rate responses to cytokinins on proliferating shoot-tips of banana cultivars (Musa spp.). American Journal of Agricultural and Biological Sciences, 5(2): 128-134.

Sidha, M., P. Suprasanna, V.A. Baat, U.G. Kulkarni, and B.N. Shinde. 2007. Developing somatic embryogenic culture system and plant regeneration in banana. Bhabha At. Res. Centre (BARC) Newslett, 285, 153-161.

Singh, C.V. 2018. Review on problems and its remedy in plant tissue culture. Asian $J$. Biol. Sci, 11(4): 165-172.

Sipen, P. and M.R. Davey. 2012. Effects of N6benzylaminopurine and indole acetic acid on in vitro shoot multiplication, nodulelike meristem proliferation and plant regeneration of Malaysian bananas (Musa spp.). Tropical life sciences research, 23(2).

Smitha, P.D., K.R. Binoy, and A.S. Nair. 2014. Effect of TDZ on direct shoot regeneration from whole male inflorescence of four diploid banana cultivars from South India. Plant Science International, 1, 24-32.

Stewart Jr, C. N. (ed). $2^{\text {nd }}$ Ed. 2016. Plant biotechnology and genetics: principles, techniques, and applications. New Jersey: John Wiley \& Sons.

Stirk, W.A. and J. Van Staden. 2010. Flow of cytokinins through the environment. Plant Growth Regulation, 62(2): 101-116.

Strosse, H., I. Van den Houwe, and B. Panis. 2004. Banana cell and tissue culturereview. Banana improvement: Cellular, molecular biology, and induced mutations, 1-12.

Suprasanna, P., M. Sidha, and T.R. Ganapathi. 2008. Characterization of radiation induced and tissue culture derived dwarf types in banana by using a SCAR marker. Aust J Crop Sci, 1(1): 47-52.

Titov, S., S.K. Bhowmik, A. Mandal, M.S. Alam, and S.N. Uddin. 2006. Control of phenolic compound secretion and effect 
of growth regulators for organ formation from Musa spp. cv. Kanthali floral bud explants. Am. J. Biochem. Biotechnol, 2(3): 97-104.

Uma, S., S. Lakshmi, M.S. Saraswathi, A. Akbar, and M.M. Mustaffa. 2012. Plant regeneration through somatic embryogenesis from immature and mature zygotic embryos of Musa acuminata ssp. burmannica. In Vitro Cellular \& Developmental Biology-Plant, 48(5): 539-545.

Xiao, W., X.L. Huang, X. Huang, Y.P. Chen, X.M. Dai, and J.T. Zhao. 2007. Plant regeneration from protoplasts of Musa acuminata cv. Mas (AA) via somatic embryogenesis. Plant Cell, Tissue and Organ Culture, 90(2): 191-200.

Yudha, H., S. Rahayu, and S. Hanum. 2015. Barangan banana (Musa acuminata L.) shoots induction by application of NAA and BA based on the sources of explant basal. Jurnal Biosains, 1(2): 13-18. 